\title{
ПОТЕНЦИАЛЬНЫЕ ВОЗМОЖНОСТИ ИСПОЛЬЗОВАНИЯ ПОДКАСТОВ НА УРОКЕ ИНОСТРАННОГО ЯЗЫКА
}

\section{POTENTIAL OPPORTUNITIES FOR USING PODCASTS IN THE LESSON OF THE FOREIGN LANGUAGE}

\section{E. Lavristscheva \\ N. Abroskina \\ A. Ostroukhova}

Summary: The article reveals the theoretical and practical issues of using podcasts in the lesson of the foreign language. Special attention is paid to the analysis of sites that present podcasts recommended for using in the process of teaching English. The article offers various ways for using podcasts in teaching of listening, for the formation and improvement of speech competence.

Keywords: podcast, speech competence, distance learning, communicative competence.

\author{
Лаврищева Екатерина Владимировна \\ к.филол.н., ФГБОУ ВО «Елецкий государственный \\ университет им. И.А. Бунина» \\ eklav@mail.ru \\ Аброськина Наталия Борисовна \\ Старший преподаватель, ФГБОУ ВО «Елецкий \\ государственный университет им. И.А. Бунина» \\ abroskina-19@mail.ru \\ Остроухова Алла Владимировна \\ Старший преподаватель, Елецкий филиал \\ AHO BO «POCHOУ» \\ allaabroskina55@yandex.ru
}

Аннотация: В статье раскрываются теоретические и практические вопросы использования подкастов на уроке иностранного языка. Особое внимание уделяется анализу сайтов, на которых представлены подкасты, рекомендованные для использования в процессе обучения английскому языку. В статье предлагаются различные варианты использования подкастов при обучении аудировании, для формирования и совершенствования речевой компетенции.

Ключевые слова: подкаст, речевая компетенция, дистанционное обучение, коммуникативная компетенция.

Отечественные ученые (Е.Ю. Малушко, П.В. Сысоев и др.) дефинируют «подкаст» как аудио- или видеофайл, который может создать любой человек для бесплатного прослушивания или просмотра в сети Интернет с помощью подписки [3, с. 148; 4, с. 10].

Целью обучения иностранному языку, как учебному предмету в рамках нового федерального государственного стандарта для общего образования является дальнейшее развитие коммуникативной компетенции в области иностранного языка и её составляющих: речевой, языковой, социокультурной, компенсаторной, учебнопознавательной.

Применение подкастов и видеокастов в образовательном процессе отвечает цели обучения иностранному языку в школе. Дидактический потенциал подкастинга обусловлен техническими и дидактическими особенностями данной интернет-технологии, а именно: аутентичностью, актуальностью, компетентностью, автономностью, многоканальным восприятием, мобильностью, многофункциональностью, продуктивностью, интерактивностью [2, с. 36].

Подкаст и видеокаст, являясь особенным социальным сервисом, представляет собой аутентичный текст, который можно использовать в качестве основного или дополнительного материала для развития умения ауди- 
рования при обучении иностранному языку. Кроме того, с помощью подкастов можно формировать и совершенствовать навыки устной речи. Использование подкастов помогает репрезентировать новые материалы и лексику, способствует расширению семантического поля, позволяет тренировать языковой материал, а также служит для формирования социокультурной компетенции обучающихся.

При обучении иностранному языку сфера применения подкастов практически неограниченна: они используются не только для выполнения рецептивных заданий, но и для тренировки и контроля подготовленной и неподготовленной речи. И рецептивные, и продуктивные задания с использованием подкастов могут быть также успешно реализованы в проектной работе.

Основной целью использования подкастов на уроке/во внеурочной деятельности является, прежде всего, развитие навыков восприятия на слух при работе с фонетическим, лексическим и грамматическим материалом, а также совершенствование умений понимания иноязычной речи на слух. Так как аудирование выступает не только как самостоятельный вид речевой деятельности, но и как средство обучения говорению, письму, языковым навыкам, решать комплексные задачи обучения помогают подкасты различных жанров и категорий [1, c. 96].

На уроке иностранного языка можно использовать и отдельные отрывки подкаста, например, для написания диктанта с последующими лексико-грамматическими упражнениями, так и подкасты целиком в качестве материала для обучения аудированию или в качестве домашней работы с их последующим обсуждением на уроке.

На сегодняшний день существует достаточно большое количество сайтов с подборкой подкастов на различных иностранных языках (www.audioenglish. org,www.bbc.co.uk/worldservice/learningenglish/general/ sixminute/, www.dailyesl.com и др.), а также мобильных приложений (Daily English Listening, Luke's English Podcast App, Crazy English Speaking и др.). С помощью этих ресурсов можно самостоятельно находить интересующие ролики по определенным темам разной степени сложности или оформить подписку и получать ежедневные оповещения.

Проведенный нами анализ таких сайтов и приложений позволяет оценить их достоинства и недостатки с позиции возможности их использования для развития устных видов речевой деятельности при обучении иностранному языку. Так, сайты ВBC History of the World in 100 Objects (https://videoinfographica.com/podcasts-forenglish), где собрана серия подкастов по истории о создании, например, орудий, украшений, предметах искусства или Startalk (https://player.fm/podcasts/startalk), на котором авторы рассказывают о явлениях в астрономии, физике, химии, являются узконаправленными и ориентированы скорее на специалистов, чем на обучающихся школ.

Сайт Voice of America Learning English (https:// learningenglish.voanews.com/p/5373.html) собрал линейку подкастов информационно-новостного характера, но в речи ведущих можно слышать американский вариант английского языка. Однако, в связи с тем, что цель обращения к подкастам и видеокастам у каждого пользователя своя, недостатки с точки зрения одних являются преимуществами с точки зрения других.

Изучив ряд подкаст-сайтов, баз данных и других источников подкастов, считаем возможным назвать те, которые на наш взгляд являются наиболее эффективными для изучения английского языка:

1. ВBC Learning English Podcast. ВВС предлагает различные подкасты: News Report (новостные peпортажи), English at Work (английский на работе), Drama (классические британские произведения) и т. д. Наиболее популярными являются «6 Minute English» и «The English We Speak». Все подкасты ВBC бесплатны [7].

2. Luke's ENGLISH Podcast. Автор этого подкаста - Люк Томпсон, преподаватель английского языка из Лондона. По сути, данные подкасты - это записи разговоров с друзьями, знакомыми, членами семьи или интервью со случайными прохожими, которые позволяют вам слушать живой английский язык. В основном аудиозапись занимает больше часа, ее можно слушать в свободное от учебы время. Подкаст бесплатный [9].

3. Breaking News English Podcast. Эта страница представляет собой коллекцию подкастов, которые обновляются каждые два дня и сообщают о текущих событиях [5].

4. Learn English Podcast om British Council. Сайт очень информативен и предлагает подборку подкастов, ориентированных на уровень знания языка от pre-intermediate (CEFR level A2) до intermediate (CEFR level B1). Эти аудиозаписи были сделаны посольством Великобритании совместно с другими организациями для легкого и увлекательного изучения английского языка. Каждая запись имеет соответствующий скрипт, доступ к которому облегчает понимание и который является важным элементом для учителя при разработке урока. Learn English Podcast от British Council предлагает большое количество статей, стихов, историй и записей на разные темы. На этой странице представлен широкий спектр различных материалов для формирования всех видов деятельности: подкасты на различные темы, аудиокниги, грамматические и лексические материалы, видеоматериалы по страноведению. Все материалы бесплатны [8]. 
Таким образом, современные информационные технологии позволяют сделать процесс обучения иностранному языку максимально эффективным и при этом интересным для обучающихся. С помощью глобальной сети Интернет можно получить доступ к большому объему информации на различные темы, что создает условия для самообразования, расширения кругозора, дальней- шего образования. И, следовательно, в процессе обучения иностранному языку необходимо в полной мере учитывать те изменения в современном обществе, которые направлены на то, чтобы максимально раскрыть индивидуальные способности и таланты человека и на этой основе сформировать профессионально и социально компетентную, мобильную личность.

\section{ЛИТЕРАТУРА}

1. Гальскова Н.Д. Современная методика обучения иностранным языкам: Пособие для учителя / Н.Д. Гальскова. — 2-е изд., перераб. и доп.— М.: АРКТИ, 2003. - $192 \mathrm{C}$.

2. Коган М.С. Использование подкастов для развития коммуникативных навыков на занятиях по английскому // Материалы XXXIX международной филологической конференции. Секция делового иностранного языка. Вып.4. СПб.: Культ-информ-пресс, 2010. - С. 35-38.

3. Малушко Е.Ю. Критерии отбора подкастов для формирования иноязычной аудитивной компетенции у студентов вузов // Научные проблемы гуманитарных исследований, 2011. - №6. - С.146-153.

4. Сысоев П.В., Евстигнеев, М.Н. Технологии Веб 2.0: Социальный сервис подкастов в обучении иностранному языку // Иностранные языки в школе, 2009. № 6. - C. 8-11.

5. Breaking News English Home [Электронный ресурс]. URL: https://breakingnewsenglish.com/podcast.html

6. Corbeil J. C. The Macmillan Visual Dictionary. M: 1992. - 862 c.

7. Learning english [Электронный ресурc]. URL: http://www.bbc.co.uk/worldservice/learningenglish

8. Learn english. British council [Электронный ресурс]. URL: https://learnenglish.britishcouncil.org

9. Luke's english Podcast [Электронный ресурс]. URL: https://teacherluke.co.uk/

\section{๑ Лаврищева Екатерина Владимировна (eklav@mail.ru), Аброськина Наталия Борисовна (abroskina-19@mail.ru), Остроухова Алла Владимировна (allaabroskina55@yandex.ru).}

Журнал «Современная наука: актуальные проблемы теории и практики»

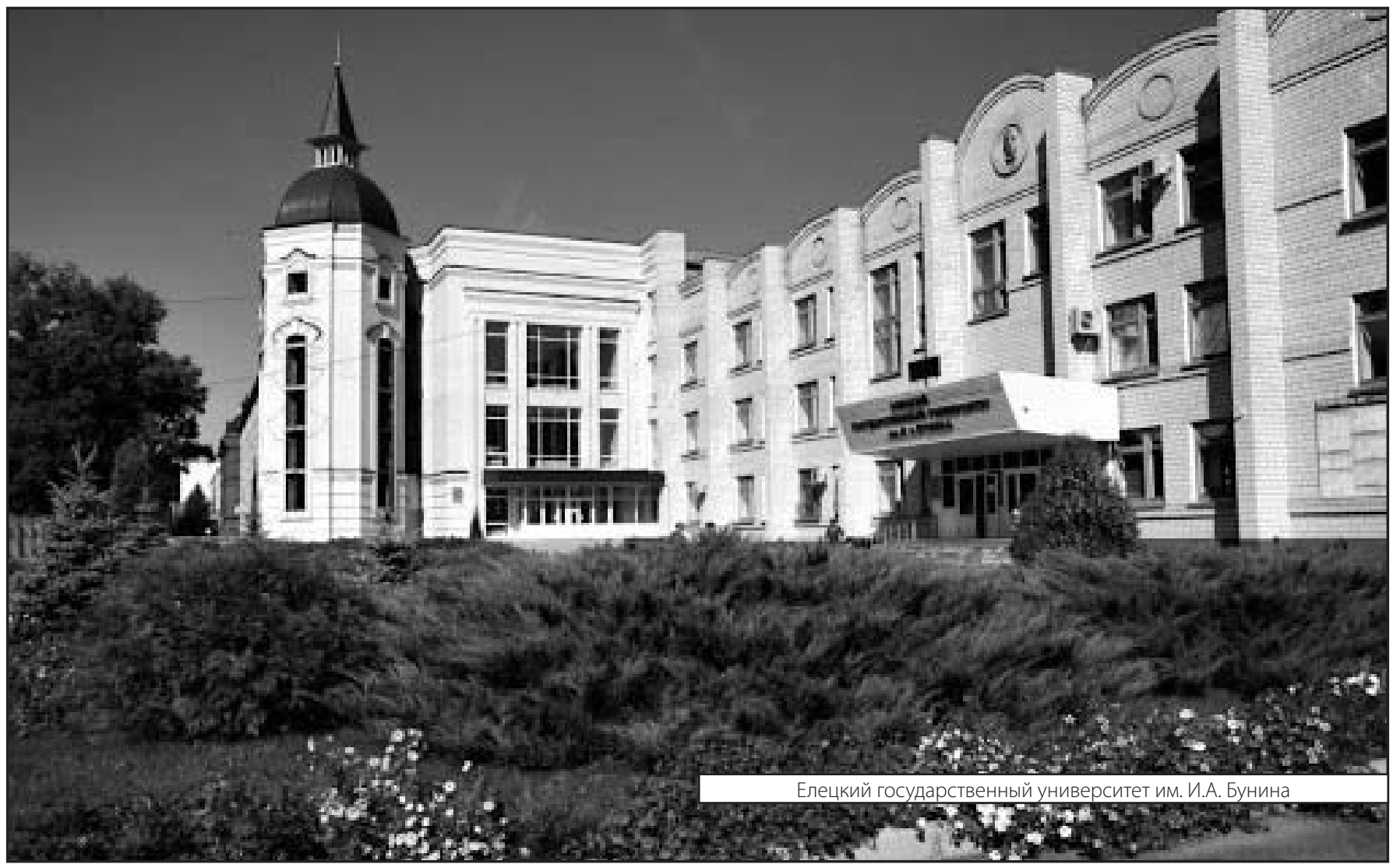

